\title{
Multiple knickpoints in an alluvial river generated by a single instantaneous drop in base level: experimental investigation
}

\author{
A. Cantelli ${ }^{1}$ and T. Muto ${ }^{2}$ \\ ${ }^{1}$ Shell International Exploration and Production, Houston, Texas, USA \\ ${ }^{2}$ Graduate School of Fisheries Science and Environmental Studies, Nagasaki University, 1-14 Bunkyomachi, \\ Nagasaki 852-8521, Japan
}

Correspondence to: A. Cantelli (alessandro.cantelli@shell.com)

Received: 6 September 2013 - Published in Earth Surf. Dynam. Discuss.: 17 October 2013

Revised: 5 March 2014 - Accepted: 24 March 2014 - Published: 5 May 2014

\begin{abstract}
Knickpoints often form in bedrock rivers in response to base-level lowering. These knickpoints can migrate upstream without dissipating. In the case of alluvial rivers, an impulsive lowering of base level due to, for example, a fault associated with an earthquake or dam removal commonly produces smooth, upstreamprogressing degradation; the knickpoint associated with suddenly lowered base level quickly dissipates. Here, however, we use experiments to demonstrate that under conditions of Froude-supercritical flow over an alluvial bed, an instantaneous drop in base level can lead to the formation of upstream-migrating knickpoints that do not dissipate. The base-level fall can generate a single knickpoint, or multiple knickpoints. Multiple knickpoints take the form of cyclic steps, that is, trains of upstream-migrating bedforms, each bounded by a hydraulic jump upstream and downstream. In our experiments, trains of knickpoints were transient, eventually migrating out of the alluvial reach as the bed evolved to a new equilibrium state regulated with lowered base level. Thus the allogenic perturbation of base-level fall can trigger the autogenic generation of multiple knickpoints which are sustained until the alluvial reach recovers a graded state.
\end{abstract}

\section{Introduction}

Knickpoints are zones of locally steepened bed slope in the long profiles of rivers. They are most commonly observed in rivers incising into bedrock (e.g. Crosby and Whipple, 2006) or a cohesive substrate (e.g. Papanicolaou et al., 2008). When sufficiently sharp, they take the form of waterfalls or head cuts (e.g. Hayakawa and Matsukura, 2003; Bennett and Alonso, 2006). They may also be manifested, however, as less steep knickzones (Hayakawa and Oguchi, 2006). Although the position of a knickpoint can stabilize in some cases (e.g. Bennet et al., 2000), a migrating knickpoint invariably recedes upstream (e.g. the analysis of 236 knickpoints in Crosby and Whipple, 2006). Shen et al. (2012) reports a rapid response in the lower Mississippi River to sea level forcing. Terrace formation after a sea-level fall in the Mississippi River basin extended to $600 \mathrm{~km}$ upstream within
$10 \mathrm{ky}$, which happened over a very short time compared to the basin response time. The study, even though the flow is supercritical in the experiment, demonstrates how the system responds to a base-level fall, generates multiple knickpoints, and reaches a new equilibrium, and also show time fraction of individual knickpoint migration relative to the basin equilibrium timescale. Knickpoint formation and migration has been modeled successfully in laboratory experiments using a model bedrock or cohesive material. Knickpoints are usually initiated by emplacing an initial knickzone along a channel, making a step elevation drop at the downstream end or impulsively lowering base level at some point during the experiment. Gardner (1983) found that knickpoints in homogeneous model bedrock generated by successive base level drops tended to decay as they migrated upstream. Numerous studies, however, have shown that in cases with heterogeneous model bedrock (e.g. alternating cohesive and 
noncohesive layers), knickpoints can evolve to an approximately self-preserving state as they migrate upstream (e.g. Holland and Pickup, 1976; Stein and LaTray, 2002). Hasbargen and Paola (2000) observed the autogenic formation and regression of successive knickpoints in a homogeneous model bedrock as base level was lowered at a constant rate. These knickpoints seem likely due to mechanism of incisional cyclic steps studied theoretically by Parker and Izumi (2000), observed in the field by Fildani (2006) experimentally in a homogeneous model bedrock by Brooks (2001) and formed by turbidity currents by Toniolo and Cantelli (2007).

Experiments that aim to produce knickpoints or knickzones have also been performed in noncohesive sediment. Brush and Wolman (1960) found that an oversteepened reach dissipated under such conditions. Lee and Hwang (1994), supporting this notion, further found that an initially vertical face created by base-level lowering tended to decay rapidly in time as the bed degraded, so that a knickpoint was not formed. Cantelli et al. $(2004,2008)$ verified this result in the course of experimental and numerical studies of dam removal.

Under the right conditions of Froude-supercritical flow, multiple knickpoints can form under quasi-equilibrium conditions (Winterwerp et al, 1992; Taki et al., 2005; Yokokawa et al., 2011). These knickpoints take the form of cyclic steps, that is, trains of upstream-migrating bedforms, each bounded by hydraulic jumps and can form under conditions of constant stationary base level, with new steps forming at the downstream end of the reach as previously formed steps migrate out of the reach. Muto et al. (2012) have observed similar quasi-equilibrium trains of cyclic steps on the alluvial top set of prograding deltas.

Here we document experiments demonstrating the autogenic formation of transient trains of upstream-migrating knickpoints in noncohesive alluvium, triggered by an impulsive lowering of base level. That is, multiple knickpoints, in the form of cyclic steps, can be autogenously generated in response to the perturbation of a sudden base-level drop. Such autogenic knickpoints eventually disappear as the alluvial reach regrades to lowered base level.

\section{Experimental setup and procedures}

Physical experiments to explore the autogenic response of alluvial rivers to a discrete drop in base level were performed with experimental facilities at Nagasaki University. An alluvial river was built within a narrow, transparent acrylic flume with a length of $4.3 \mathrm{~m}$ and a width of $2.0 \mathrm{~cm}$. The bed of the flume had a slope of $0.218\left(7.1^{\circ}\right)$; it defined the basement on top of which an alluvial reach with a lower slope formed. The flume was suspended inside a larger glass-walled tank with a length of $4.5 \mathrm{~m}$, a depth of $1.3 \mathrm{~m}$ and a width of $1.0 \mathrm{~m}$ (Fig. 1a). The flow in the flume was subaerial, with water

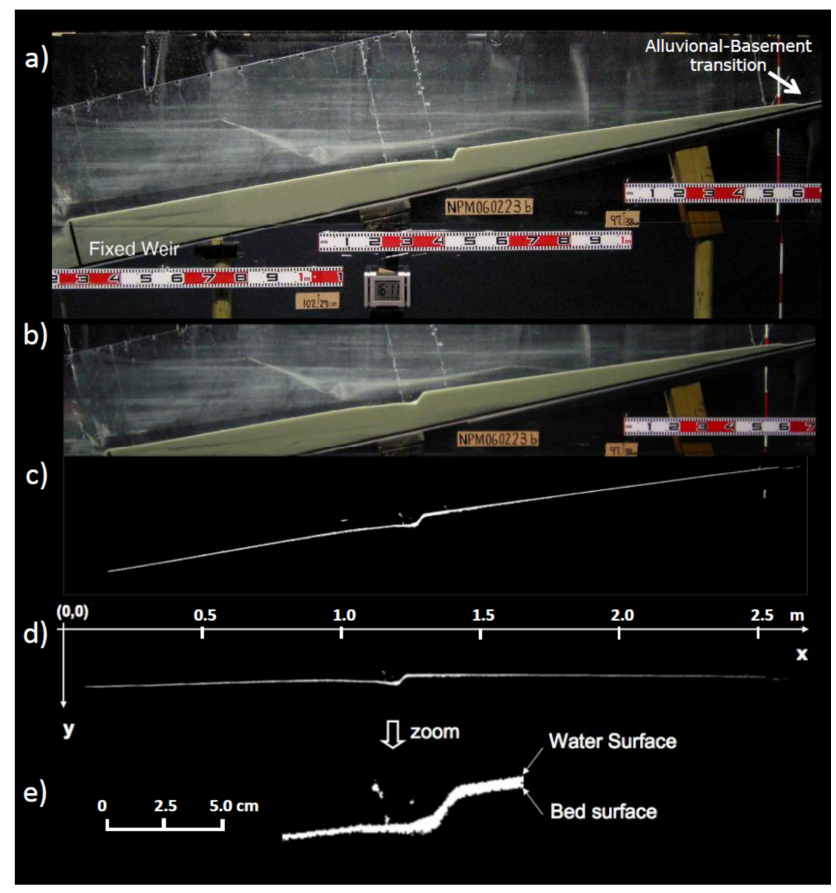

Figure 1. (a) Experimental setup showing the flume, the deposit and the weir; (b) cropped image used for data imaging elaboration; (c) digital image obtained by applying the color threshold to the original image, showing the contrast between white and black that allowed extraction of water depth; (d) the same image, rotated to be parallel to the top set before weir removal; (e) magnified image of the knickpoint area; some extraneous spots are present due to reflections from the glass of the flume wall.

draining into ponded water in the tank over a free overfall created by a weir.

This weir was located $2.8 \mathrm{~m}$ downstream of the upstream end of the flume. It was composed of two essential parts: the $15 \mathrm{~cm}$ high lower portion that was fixed to the flume floor, and the removable upper portion that was $2.5 \mathrm{~cm}, 5.0 \mathrm{~cm}$, $7.5 \mathrm{~cm}, 10.0 \mathrm{~cm}$ or $15.0 \mathrm{~cm}$ in height. Removal of this upper portion was a simulation of an instantaneous base-level fall that varied runs.

Prior to the onset of each run, the alluvial river upstream of the weir aggraded with sediment and water supplied at constant rates from the upstream end of the flume. This was done until the alluvial river became graded, i.e. a perfect sedimentbypass system associated with no net erosion and no net deposition. This experimental alluvial configuration was similar, but not identical, to that used by Muto and Swenson (2006) who used the same tank facilities to build a graded river in a deltaic system. In the experiments reported here, base level was maintained by weir as a free overfall, whereas in the experiments of Muto and Swenson (2006), water surface functioned as base level and was continuously lowered at a constant rate. In the latter experiments, a graded state was attained in a moving-boundary system, in which sediment 
Table 1. List of the experimental conditions.

\begin{tabular}{ccccccc}
\hline & $\begin{array}{c}\text { Sediment feed } \\
\text { rate } Q_{\mathrm{s}}\left(\mathrm{g} \mathrm{s}^{-1}\right)\end{array}$ & $\begin{array}{c}\text { Upstream water } \\
\text { discharge } Q_{\mathrm{w}}\left(\mathrm{g} \mathrm{s}^{-1}\right)\end{array}$ & $Q_{\mathrm{s}} / Q_{\mathrm{w}}$ & $\begin{array}{c}\text { Mean grain } \\
\text { size } D_{50}(\mathrm{~mm})\end{array}$ & $\begin{array}{c}\text { Drop of base } \\
\text { level } \Delta H(\mathrm{~cm})\end{array}$ & $\begin{array}{c}\text { Graded } \\
\text { Slope \% }\end{array}$ \\
\hline Run 1 & 0.90 & 3.74 & 0.24 & 0.2 & 5.0 & 7.5 \\
Run 2 & 0.90 & 6.34 & 0.14 & 0.2 & 5.0 & 7.2 \\
Run 3 & 0.90 & 7.42 & 0.12 & 0.2 & 5.0 & 6.1 \\
Run 4 & 0.90 & 15.34 & 0.06 & 0.2 & 5.0 & 4.0 \\
Run 5 & 0.90 & 7.25 & 0.12 & 0.2 & 2.5 & 6.2 \\
Run 6 & 0.90 & 7.19 & 0.13 & 0.2 & 7.5 & 5.7 \\
Run 7 & 0.90 & 7.30 & 0.12 & 0.2 & 10.0 & 5.3 \\
Run 8 & 0.90 & 7.14 & 0.13 & 0.2 & 15.0 & 5.3 \\
\hline
\end{tabular}

fed to the alluvial top set of the model river allowed continued delta progradation.

The alluvial deposit always had a slope that was significantly lower than the basement. Because of this, the upstream end of the alluvial reach was characterized by a relatively sharp alluvial-basement transition (Fig. 1a; Muto, 2001). This transition migrated either upstream or downstream during the approach to grade, but stabilized when grade was attained. This inherent behavior of the alluvial-basement transition was recognized in the experiments of Muto and Swenson $(2005 \mathrm{a}, 2006)$ where alluvial grade was sustained in a deltaic, moving-boundary system.

In each run of the present experiments, after grade was attained, the upper portion of the weir was removed so as to cause sudden base-level drop, and force the generation of a knickpoint at the downstream end of the alluvial reach. Water and sediment feed rates were kept constant at particular (Table 1) values during the entire run (i.e. both before and after weir removal). Each run was continued until the alluvial river recovered a graded configuration that was regulated with the top of the new, lower weir. The recovery of grade was judged by the standstill of alluvial-basement transition and the straightness of the river profile (Muto and Swenson, 2005b).

The behavior of the knickpoint as generated in each experiment was recorded in digital images that were taken every five seconds. These images were later analyzed using digital processing tools available in Matlab. More specifically, artificial light was allocated to each pixel of the image, so as to enhance the color contrast between the flowing water and the bed. The numeric matrix of each pixel color was filtered with a threshold chosen to transform the layer of flowing water to white and the remainder of the image to black (Fig. $1 \mathrm{~b}$ and c).

The image was then rotated by an angle equal to the initial delta top set slope in order to highlight the elevation drop across a knickpoint (Fig. 1d). A close-up image of the knickpoint highlights the spatial change in water depth (Fig. 1e). Due to the small scale of the experiment no direct flow measurements were performed. However, flow depths detected by digital image analysis were found to be within the range of $1-4 \mathrm{~mm}$.

All runs were performed using sediments with a density of $2.65 \mathrm{~g} \mathrm{~cm}^{-3}$ and a median size $D_{50}$ of $0.2 \mathrm{~mm}$. Sediment discharge $Q_{\mathrm{s}}$ was kept constant at $0.90 \mathrm{~g} \mathrm{~s}^{-1}$. Eight runs were conducted using different drops in weir height and different water discharges $Q_{\mathrm{w}}$. In four of these (Runs 1 to 4), the drop in weir height $\Delta H$ was held constant at $5.0 \mathrm{~cm}$, but $Q_{\mathrm{w}}$ was varied. In the other four (Runs 5-8), $Q_{\mathrm{w}}$ was held constant but the drop in weir height was varied. Table 1 summarizes the combinations of experimental conditions. Due to the narrowness of the flume, the alluvial bed was always completely inundated by water.

General reproducibility of the experiments was verified with another set of runs that were conducted repeatedly under the same initial conditions as Runs $1-8$, though the number of multiple knickpoints generated in supplementary runs were not precisely the same as here reported. The latter could arise from minor instability of the experimental conditions adopted. As for Runs 1 and 8 and their supplementary runs, there occurred only a single knickpoint during the entire run time.

\section{Results of the experiments}

In all eight experiments, a single perturbation caused by the sudden removal of the top portion of the weir generated multiple knickpoints. A common pattern of knickpoint formation and subsequent upstream migration is well represented by Run 3 (Fig. 2). At time $t=30 \mathrm{~s}$, significant erosion without a definable knickpoint occurs in the proximity of the weir right after removal of the top weir (Fig. 2a). This event represents the initiation of knickpoint formation. At $t=220 \mathrm{~s}$ (Fig. 2b) erosion and lowering of the alluvial bed propagates upstream, but the alluvial slopes are still gentle overall, with no sharp knickpoint. By $t=370 \mathrm{~s}$ (Fig. 2c), a knickpoint with a sharp face develops, and by $t=450 \mathrm{~s}$ (Fig. 2d), the knickpoint is well defined. It continues to propagate upstream until it reaches the alluvial-basement transition, as documented in Fig. 2e-g $(t=520 \mathrm{~s}, 670 \mathrm{~s}, 760 \mathrm{~s})$. The arrival of this first 
a

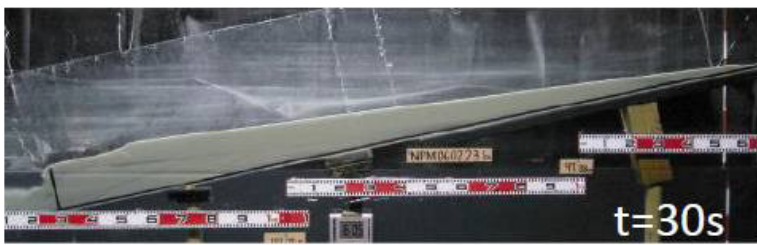

b

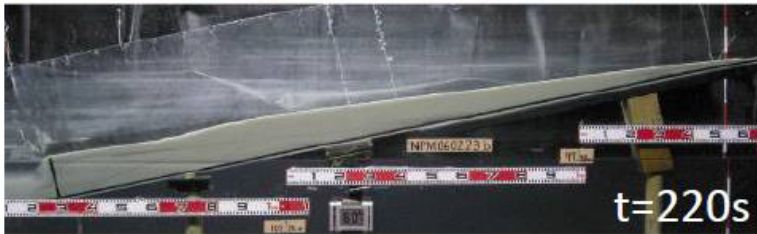

C

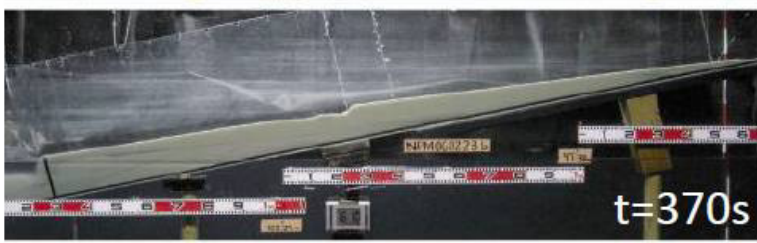

e
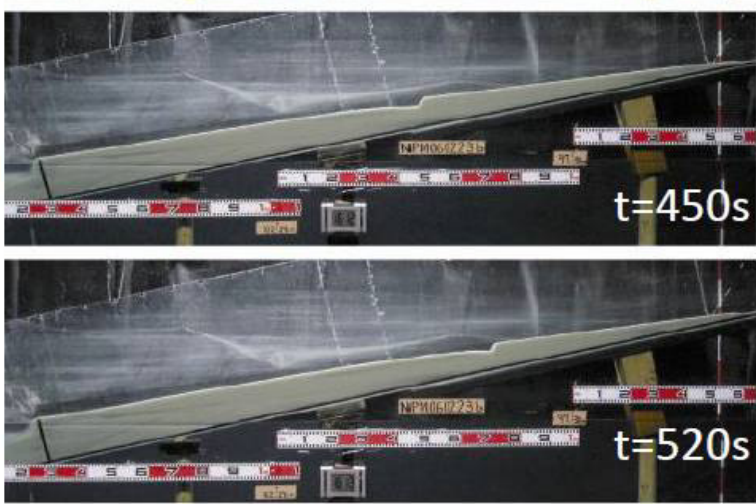

f

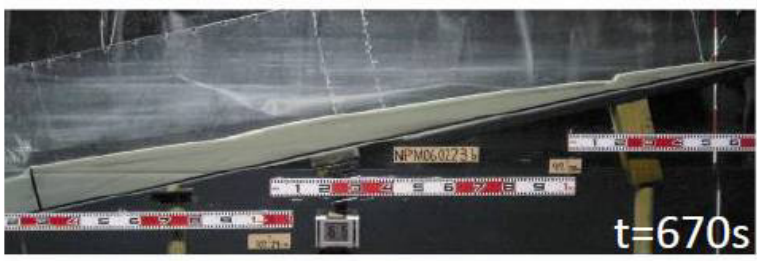

g

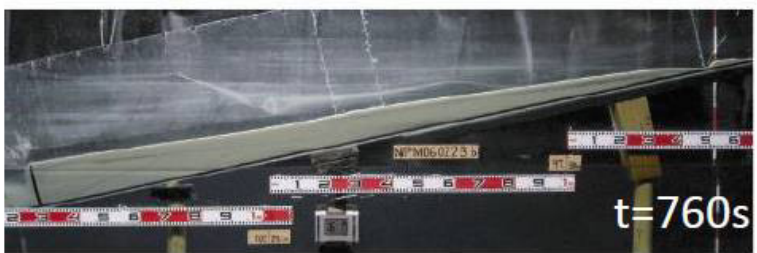

Figure 2. Sequential images of river profile in Run 3, illustrating the formation and upstream migration to the alluvial-basement transition of a knickpoint.

knickpoint at the alluvial-basement transition, however, does not correspond to the attainment of a new graded state of the river. Instead, it is followed by intermittent arrival of multiple knickpoints, with the river eventually recovering grade only after the last knickpoint has migrated out of the reach.

Substantially the same process of multiple knickpoint formation and migration was observed in Runs 2, 4, 5, 6 and 7.
In Runs 1 and 8, where only a single knickpoint was created by the removal of the upper weir, the bed slope first became steeper, and then became gentler again to re-approach grade. While the reason for this different behavior is not clear, it is worth noting that (a) Run 1 was conducted with a very low value of $Q_{\mathrm{w}}$, and (b) Run 8 was conducted with the highest value of weir height lowering $\Delta H$, i.e. $15 \mathrm{~cm}$, causing the loss of a very large volume of sediment as soon as the weir was removed.

Figure 3 shows the geomorphic evolution of the alluvial reach observed in Run 2. In the figure, change in elevation relative to the initial alluvial plane is expressed in terms of index color. The coordinate system has been rotated to be parallel to the initial alluvial graded profile in order to highlight the elevation difference at each knickpoint. For the purposes of plotting, the datum of the coordinate system has been arbitrarily placed $0.98 \mathrm{~m}$ below and parallel to the initial bed profile. Thus an "elevation" of,for example, $0.94 \mathrm{~m}$ corresponds to $4 \mathrm{~cm}$ downward normal from the initial bed profile. The bottom axis shows time, the left vertical axis shows distance downstream from the feed point, and the color bar next to the right axis documents "elevation" above the arbitrary datum. The plot includes a time interval of $120 \mathrm{~s}$ before $t=0$, when the weir was lowered by $5 \mathrm{~cm}$ to an "elevation" of $0.93 \mathrm{~m}$. This has been done to show a graded profile prevailing before the lowering of the weir. A series of five prominent knickpoints, along with two weaker knickpoints, can be seen to be migrating upstream.

Figure 3 also shows that the first knickpoint (knickpoint 1) took $370 \mathrm{~s}$ to migrate upstream over the entire alluvial reach ( $2.3 \mathrm{~m}$ long) to the alluvial-basement transition. The average rate of migration was thus $6 \mathrm{~mm} \mathrm{~s}^{-1}$. Immediately after the knickpoint reached the alluvial-basement transition, the alluvial reach was modestly reduced in length to $2.20 \mathrm{~m}$.

Four more prominent knickpoints formed: knickpoint 2 at $t=250 \mathrm{~s}$, knickpoint 3 at $t=510 \mathrm{~s}$, knickpoint 4 at $t=1125 \mathrm{~s}$ and knickpoint 5 at $t=1810 \mathrm{~s}$. The migration rate of these knickpoints varied between 5 and $7.5 \mathrm{~mm} \mathrm{~s}^{-1}$. Two weak knickpoints, which were generated between knickpoints 3 and 4 (Fig. 3), are labeled as knickpoints 3a and 4a. These were accompanied by a relatively insignificant change in elevation. They formed in the middle of the alluvial reach rather than at the downstream weir, and had a higher migration velocity of about $10 \mathrm{~mm} \mathrm{~s}^{-1}$.

The elevation and length of the alluvial reach decreased during this process, and then gradually returned to the values characteristic of the graded state. The time interval and distance between knickpoint occurrences increased in time, as illustrated in Fig. 3 with black arrows.

Table 2 summarizes our observations of the knickpoints. The headings have the following meanings. In most cases, "start time" is the time when the knickpoint was initiated at the weir. Some knickpoints, however, formed upstream of the weir. "End time" is the time when the knickpoint vanished; this usually but not always corresponds to the time 


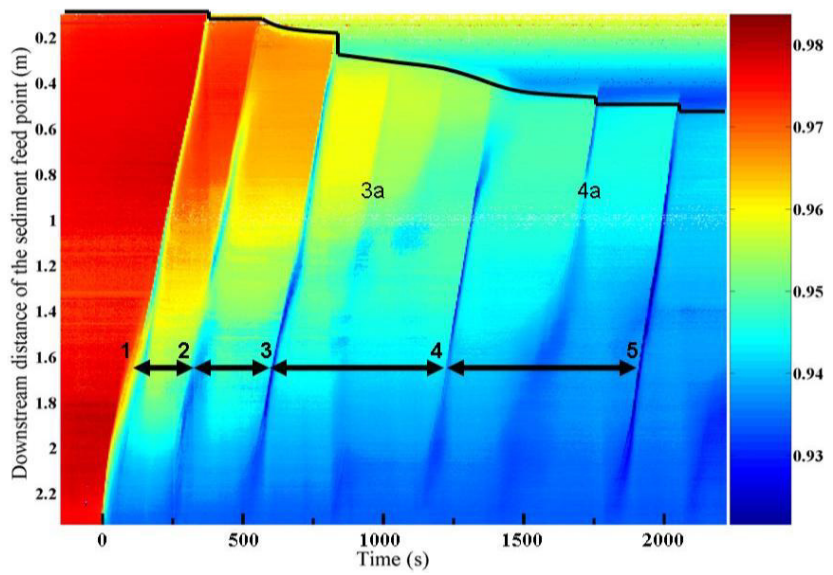

Figure 3. Geomorphic evolution of the alluvial reach in Run 2. Plot illustrating the upstream migration of five prominent knickpoints, and two weak knickpoints, in response to the lowering of the weir by $5 \mathrm{~cm}$ at $t=0$. The run in question is Fig. 2. The bottom axis is time elapsed after the removal of the upper weir. For $120 \mathrm{~s}$ proceeding to $t=0$, the entire alluvial river was graded (i.e. antecedent graded profile). Color index bar to the right documents relative bed elevation, as explained in the text.

when the knickpoint reached the alluvial-basement transition. "Runout" denotes the distance the knickpoint traveled. "Volume" denotes the total volume of sediment removed from the initial graded state to final the graded state.

The numbers of knickpoints that formed are as follows. Run 1-1; Run $2-5$ strong and 2 weak; Run $3-2$; Run $4-$ 2; Run 5-1; Run 6-6; Run 7-2; and Run 8-1. Thus multiple knickpoints formed in most of the runs. The column "Alluvial length" in Table 2 documents how the alluvial reach shortened as knickpoints formed and migrated upstream. The alluvial length at the final grade is shorter than that at antecedent grade because for the same bed slope, a decrease in weir height results in a shorter distance from weir to the intersection with the basement. Otherwise, there was no significant difference between the final and antecedent graded states of the river.

Runs 1-4 were conducted with the same weir height lowering $(5 \mathrm{~cm})$, but with different water discharges $Q_{\mathrm{w}}$ (ranging from 3.74 to $15.34 \mathrm{~mL} \mathrm{~s}^{-1}$ in order of run). As noted above, the alluvial reach must be shorter at final equilibrium than antecedent equilibrium, because a lower weir height at the same alluvial bed slope causes the alluvial reach to intersect the steeper basement farther downstream. In the absence of knickpoints, it might be thought that the alluvial length would decrease continuously in time. Figure 4 shows that this was indeed the case for Run 8, for which only one weak knickpoint formed, and later dissipated before reaching the alluvial-bedrock transition (see Table 2). In all the other runs, however, the decrease of alluvial length was sharply discontinuous in time, with a sudden drop corresponding to the arrival time of a step at the alluvial-basement transition.

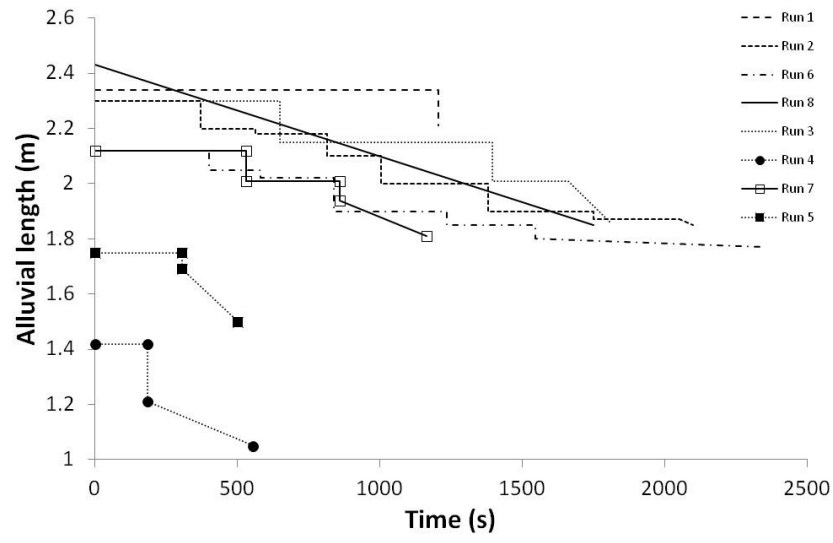

Figure 4. Plots of the time variation of alluvial length for each experiment.

\section{Discussion and conclusions}

This work demonstrates that a single base-level drop can generate multiple knickpoints that lead to a new equilibrium profile. Although detailed measurements of flow were not conducted during the experiments, the Froude-supercritical flow was manifest, both at the graded and transient states. Froude-supercritical flow can generate a variety of bed states in alluvium, including plane beds, upstream- or downstreammigrating antidunes and cyclic steps. For a phase diagram of these bedforms see Muto et al. (2012). Under the right conditions, upstream-migrating cyclic steps of permanent (rather than transient) form can manifest themselves in terms of trains of sharp knickpoints (Taki and Parker, 2005; Yokokawa et al., 2011). In the case of sea level drop, alluvial rivers are largely connected with subcritical flow. Applicability of this work is therefore to be search in different cases, such as fault exposures or at small drainage basin scale where different branches of river network incise a valley, and create a local drop in level with the confluent creeks merging with the river. The latter situation, in particular, is well documented by Hasbargen and Paola (2000). In a more engineering application, this work can be linked with dam removal where an important question is related to the morphology consequences to dam removal and how and if the final new equilibrium profile can be reached and in which way. Last but not least in the deep-water environment, the seabed presents many examples of knickpoints (e.g., off-shore California) (Fildani et al., 2006), and often subsidence due to, for example, salt tectonic in the gulf of Mexico can generate the right condition to trigger similar mechanisms with supercritical turbidity currents.

In our experiments, the graded state was in the planebed regime. The transient trains of knickpoints caused by sudden base-level drop, however, also manifested themselves as sharp cyclic steps, each bounded by hydraulic jumps that were readily evident with the naked eye. We thus 
Table 2. Characteristics of the knickpoints.

\begin{tabular}{|c|c|c|c|c|c|c|c|c|}
\hline Knickpoint \# & $\begin{array}{l}\text { Start } \\
\text { time } \\
{[\mathrm{s}]}\end{array}$ & $\begin{array}{l}\text { End } \\
\text { time } \\
{[s]}\end{array}$ & $\begin{array}{l}\text { Runout } \\
{[\mathrm{m}]}\end{array}$ & $\begin{array}{l}\text { Alluvial } \\
\text { length } \\
{[\mathrm{m}]}\end{array}$ & $\begin{array}{l}\text { Velocity of } \\
\text { migration } \\
{\left[\mathrm{m} \mathrm{s}^{-1}\right]}\end{array}$ & $\begin{array}{l}\text { Weir } \\
\text { height } \\
{[\mathrm{m}]}\end{array}$ & $\begin{array}{l}\text { Volume } \\
{\left[\mathrm{m}^{3}\right]}\end{array}$ & Note \\
\hline $\begin{array}{l}\text { Run } 1 \\
1\end{array}$ & 0 & $\begin{array}{l}0 \\
1205\end{array}$ & & $\begin{array}{l}2.34 \\
2.21\end{array}$ & & $5.00 \times 10^{-2}$ & 0.11375 & $\begin{array}{l}\text { A single knickpoint that reached } \\
\text { the alluvial-basement } \\
\text { transition }\end{array}$ \\
\hline $\begin{array}{l}\text { Run } 2 \\
1 \\
2 \\
3 \\
3 \mathrm{a} \\
4 \\
4 \mathrm{a} \\
5\end{array}$ & $\begin{array}{l}0 \\
250 \\
520 \\
810 \\
1135 \\
1575 \\
1812\end{array}$ & $\begin{array}{l}0 \\
370 \\
562.5 \\
814 \\
1004 \\
1380 \\
1750 \\
2051\end{array}$ & $\begin{array}{l}2.18 \\
2.19 \\
2.10 \\
1.55 \\
1.91 \\
1.30 \\
1.84\end{array}$ & $\begin{array}{l}2.3 \\
2.2 \\
2.18 \\
2.1 \\
2 \\
1.9 \\
1.87 \\
1.85\end{array}$ & $\begin{array}{l}5.90 \times 10^{-3} \\
7.00 \times 10^{-3} \\
7.13 \times 10^{-3} \\
7.99 \times 10^{-3} \\
7.78 \times 10^{-3} \\
7.43 \times 10^{-3} \\
7.70 \times 10^{-3}\end{array}$ & $5.00 \times 10^{-2}$ & 0.10375 & \\
\hline $\begin{array}{l}\text { Run } 3 \\
1 \\
2\end{array}$ & $\begin{array}{l}0 \\
605 \\
1395\end{array}$ & $\begin{array}{l}0 \\
650 \\
1395 \\
1810\end{array}$ & $\begin{array}{l}2.15 \\
3.41\end{array}$ & $\begin{array}{l}2.3 \\
2.15 \\
2.01 \\
1.86\end{array}$ & $\begin{array}{l}3.31 \times 10^{-3} \\
4.32 \times 10^{-3}\end{array}$ & $5.00 \times 10^{-2}$ & 0.104 & \\
\hline $\begin{array}{l}\text { Run } 4 \\
1 \\
2\end{array}$ & $\begin{array}{l}0 \\
230\end{array}$ & $\begin{array}{l}0 \\
185 \\
555\end{array}$ & $\begin{array}{l}1.20 \\
3.75\end{array}$ & $\begin{array}{l}1.42 \\
1.21 \\
1.05\end{array}$ & $\begin{array}{l}6.49 \times 10^{-3} \\
1.15 \times 10^{-2}\end{array}$ & $5.00 \times 10^{-2}$ & 0.06175 & \\
\hline $\begin{array}{l}\text { Run } 5 \\
1 \\
2\end{array}$ & $\begin{array}{l}0 \\
305\end{array}$ & $\begin{array}{l}0 \\
305 \\
500\end{array}$ & $\begin{array}{l}2.30 \\
2.20\end{array}$ & $\begin{array}{l}1.75 \\
1.69 \\
1.5\end{array}$ & $\begin{array}{l}7.54 \times 10^{-3} \\
1.13 \times 10^{-2}\end{array}$ & $2.50 \times 10^{-2}$ & 0.04063 & \\
\hline $\begin{array}{l}\text { Run } 6 \\
1 \\
2 \\
3 \\
4 \\
5 \\
6\end{array}$ & $\begin{array}{l}0 \\
100 \\
500 \\
800 \\
960 \\
1480\end{array}$ & $\begin{array}{l}0 \\
400 \\
580 \\
840 \\
1235 \\
1545 \\
2355\end{array}$ & $\begin{array}{l}2.20 \\
2.20 \\
2.17 \\
2.06 \\
2.00 \\
2.75\end{array}$ & $\begin{array}{l}2.11 \\
2.05 \\
2.02 \\
1.9 \\
1.85 \\
1.8 \\
1.77\end{array}$ & $\begin{array}{l}5.50 \times 10^{-3} \\
4.58 \times 10^{-3} \\
6.38 \times 10^{-3} \\
4.75 \times 10^{-3} \\
3.41 \times 10^{-3} \\
3.15 \times 10^{-3}\end{array}$ & $7.50 \times 10^{-2}$ & 0.1455 & \\
\hline $\begin{array}{l}\text { Run } 7 \\
1 \\
2\end{array}$ & $\begin{array}{l}0 \\
515 \\
860\end{array}$ & $\begin{array}{l}0 \\
530 \\
860 \\
1165\end{array}$ & $\begin{array}{l}4.06 \\
2.81\end{array}$ & $\begin{array}{l}2.12 \\
2.01 \\
1.94 \\
1.81\end{array}$ & $\begin{array}{l}7.67 \times 10^{-3} \\
8.15 \times 10^{-3}\end{array}$ & $1.00 \times 10^{-1}$ & 0.1965 & \\
\hline $\begin{array}{l}\text { Run } 8 \\
1\end{array}$ & 0 & $\begin{array}{l}0 \\
1750\end{array}$ & & $\begin{array}{l}2.43 \\
1.85\end{array}$ & & $1.50 \times 10^{-1}$ & 0.321 & $\begin{array}{l}\text { A single knickpoint that vanished } \\
\text { before reaching the alluvial-basement } \\
\text { transition }\end{array}$ \\
\hline
\end{tabular}

demonstrate for the first time that a single, sudden lowering of base level can generate a transient series of knickpoints. Although our experiments were in the Froude-supercritical range, they were evidently outside the range for the formation of permanent trains of knickpoints. The allogenic perturbation of impulsive base-level lowering, however, triggered an autogenic, transient response in terms of multiple knickpoints, taking the form of cyclic steps.

In the experiments reported here, an alluvial reach of a model river was bounded upstream by a transition to a steeper basement platform, and downstream by a weir. We first formed a graded channel with constant water and sediment feed rates, and then impulsively reduced the height of the weir. The model river eventually evolved to exactly the same graded state as the antecedent one, the only difference between the initial and final states of the river being a shortening of the alluvial reach. This shortening was mediated by lower base level; the same slope profile originating from a lower base level intersects the steeper basement platform farther downstream.

In two out of eight experiments, the evolution to the new equilibrium was mediated by the upstream migration of a single knickpoint. In one of these two experiments, the knickpoint was weak, and dissipated before reaching the alluvialbasement transition; in the second of these, the knickpoint reached the alluvial-basement transition. In the rest (i.e. six runs), transient evolution of the alluvial reach was mediated 
by two to six consecutively forming knickpoints, all of which eventually reached the alluvial-basement transition.

When multiple steps formed, the process by which equilibrium was restored at lower base level did not consist of a continuous shortening of the alluvial reach, but instead was characterized by a series of discrete reductions, each associated with the arrival of a step at the alluvial-basement transition. Thus there can be at least three modes of response of an alluvial river to impulsively lowered base level: bed degradation without knickpoints (Gardner, 1983), degradation mediated by a single transient knickpoint (Gardner, 1983, and also the present experiment illustrated with Runs 1 and 8), and bed degradation mediated by a train of transient knickpoints (as illustrated with Runs 2-7).

Despite an attempt to link the bed evolution with the characteristics of the flow, the data did not acquire the results sufficiently. In particular, estimation of water depth from the image analysis has an error range of 20-30\% due to pixel resolution. Moreover, high sediment concentration (with a max of over $50 \%$ of water discharge) and apparent cohesiveness are not negligible in the present phenomenon, which makes it difficult to model in terms of application to natural systems. A key control of the system is the sediment-transport capacity of the flow that generates knickpoints. Where a single knickpoint is insufficient to remove all the material to reach the new equilibrium state, there may well be room that multiple knickpoints are generated. The more distantly the river is from the equilibrium with a single passage of knickpoint, the more likely there occur another knickpoints on the river. In case, however, the initial drop of base level exceeds a particular magnitude, subsequent occurrence of knickpoints is unlikely and the river obtains a concave-downward profile that progressively approaches a new equilibrium. Further experiments are required to investigate this hydrodynamics of the physical process.

In summary, the set of experiments presented here highlights the possibility that multiple knickpoints are generated in response to a single discrete drop in base level, though an explanation from the fluid mechanics point of view is not sufficiently available yet.

Acknowledgements. This paper is a contribution to the National Center for Earth-surface Dynamics, a Science and Technology Center funded by the US National Science Foundation (EAR0120914). This work was also financially supported in part by a 2003-2006 Japanese Grant-in-Aid for Scientific Research B (15340171) to Tetsuji Muto, which provided travel allowance to Alessandro Cantelli. The authors highly appreciate the helpful advice and encouragement provided by Gary Parker and the great contribution provided by the reviewers Kim Wonsuck, Tom Coulthard and Brandon McElroy.

Edited by: F. Metivier

\section{References}

Bennett, S. J. and Alonso, C. V.: Turbulent flow and bed pressure within headcut scour holes due to plane reattached jets, J. Hydraul. Res., 44, 510-521, 2006.

Bennett, S. J., Robinson, K. M., Simon, A., and Hanson, G. J.: Stable knickpoints formed in cohesive sediment, Proceedings, Joint Conference on Water Resource Engineering and Water Resources Planning and Management, Minneapolis, Minnesota, United States, 30 July-2 August, 10 pp. 2000.

Brooks, P.: Experimental study of erosional cyclic steps, MS thesis, University of Minnesota, 63 pp., 2001.

Brush, L. M. and Wolman, M. G.: Knickpoint behavior in noncohesive material: A laboratory study, Geol. Soc. Am. Bull., 71, 59-74, 1960.

Cantelli, A., Paola, C., and Parker, G.: Experiments on upstreammigrating erosional narrowing and widening of an incisional channel caused by dam removal, Water Resour. Res., 40, 1-12, doi:10.1029/2003WR002940, 2004.

Cantelli, A., Wong, M., Parker, G., and Paola, C.: Numerical model linking bed and bank evolution of incisional channel created by dam removal, Water Resour. Res., 43, W07436, doi:10.1029/2006WR005621, 2008.

Crosby, B. T. and Whipple, K. X.: Knickpoint initiation and distribution within fluvial networks: 236 waterfalls in the Waipaoa River, North Island, New Zealand, Geomorphology, 82, 16-38, 2006.

Fildani, A., Normark, W., Kostic, S., and Parker, G.: Channel formation flow stripping: large-scale scour features along the Monterey East Channel and their relation to sediment waves, Sedimentology, 53, 1265-1287, 2006.

Gardner, T. W.: Experimental study of knickpoint and longitudinal profile evolution in cohesive, homogeneous material, Geol. Soc. Am. Bull., 94, 664-672, 1983.

Hayakawa, Y. and Matsukura, Y.: Recession rates of waterfalls in Boso Peninsula, Japan, and a predictive equation, Earth Surf. Proc. Land., 28, 675-684, 2003.

Hayakawa, Y. S. and Oguchi, T.: GIS analysis of fluvial knickzone distribution in Japanese mountain watersheds, Geomorphology, 111, 27-37, 2009.

Hasbargen, L. E. and Paola, C.: Landscape instability in an experimental drainage basin, Geology, 28, 1067-1070, 2000.

Holland, W. N. and Pickup, G.: Flume study of knickpoint development in stratified sediment, Geol. Soc. Am. Bull., 87, 76-82, 1976.

Lee, H. Y. and Hwang, S. T.: Migration of a backward-facing step, J. Hydraul. Eng., 120, 693-705, 1994.

Muto, T.: Shoreline autoretreat substantiated in flume experiment, J. Sediment. Res., 71, 246-254, 2001.

Muto, T. and Swenson, J. B.: Large-scale fluvial grade as a non-equilibrium state in linked depositional systems: Theory and experiment, J. Geophys. Res., 110, F03002, doi:10.1029/2005JF000284, 2005a.

Muto, T. and Swenson, J. B.: Controls on alluvial aggradation and degradation during steady fall of relative sea level: Flume experiments, in: River, Coastal and Estuarine Morphodynamics, edited by: Parker, G. and Garcia, M. H., v. 2: London, Talor and Francis, 665-674, 2005b. 
Muto, T. and Swenson, J.: Autogenic attainment of large-scale alluvial grade with steady sea-level fall: An analog tank-flume experiment, Geology, 34, 161-164, 2006.

Muto, T., Yamagishi, T., Sekiguchi, T., Yokokawa, M., and Parker, G.: The hydraulic autogenesis of distinct cyclicity in delta foreset bedding: Flume experiments, J. Sediment. Res., 82, 545-558, 2012.

Papanicolaou, A. Wilson, C., Dermisis, D., and Elhakeem, M.: The effects of headcut and knickpoint propagation on bridges in Iowa, Final Report submitted to: Iowa Department of Transportation, Highway Division, Iowa Highway Research Board, 57 pp., 2008.

Parker, G. and Izumi, N.: Purely erosional cyclic and solitary steps created by flow over a cohesive bed, J. Fluid Mech., 419, 203 238,2000 .

Shen, Z., Törnqvist, T. E., Autin, W. J., Mateo, Z. R. P., Straub, K. M., and Mauz, B.: Rapid and widespread response of the Lower Mississippi River to eustatic forcing during the last glacialinterglacial cycle, Geol. Soc. Am. Bull., 124, 690-704, 2012.

Stein, O. R. and LaTray, D. A.: Experiments and modeling of headcut migration in stratified soils, Water Resour. Res., 38, 20-1-2012, 2002.
Taki, K. and Parker, G.: Transportational cyclic steps created by flow over an erodible bed. Part 1. Experiments, J. Hydraul. Res., 43, 488-501, 2005.

Toniolo, H. and Cantelli, A.: Experiments on upstream-migrating submarine knickpoints, J. Sediment. Res., 77, 772-783, 2007.

Winterwerp, J. C., Bakker, W. T., Mastbergen, D. R., and van Rossum, H.: Hyperconcentrated sand-water mixture flows over erodible bed, J. Hydraul. Eng., 119, 1508-1525, 1992.

Yokokawa, M., Takahashi, Y., Yamamura, H., Kishima, Y., Parker, G., and Izumi, N.: Phase diagram for antidunes and cyclic steps based on suspension index, non-dimensional Chezy resistance coefficient and Froude number, Proceedings, River, Coastal and Estuarine Morphodynamics Conference, Beijing, China, 6-8 September, 7 pp., 2011. 